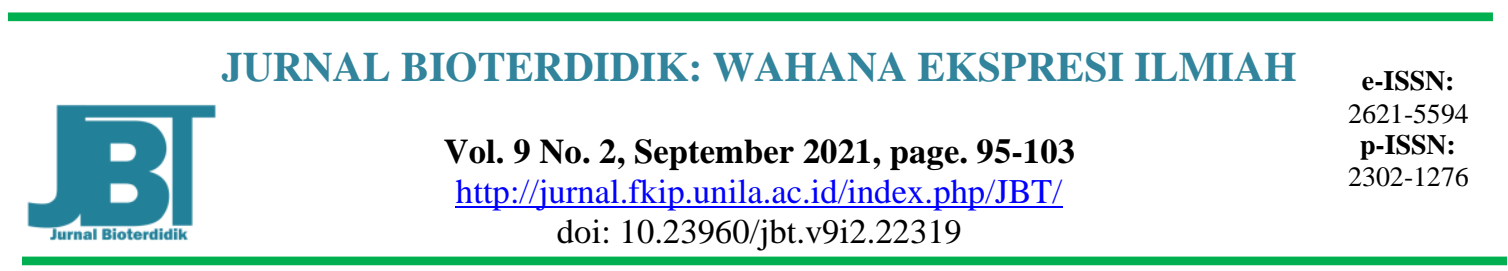

\title{
Pengembangan Buku Nonteks Biologi SMA Kelas X Berbasis Pengetahuan Etnobotani di Kabupaten Situbondo
}

\author{
Afridatul Rofi'ah*, Sulifah Aprilya Hariani, Pujiastuti \\ Pendidikan Biologi, Fakultas Keguruan dan Ilmu Pendidikan, Universitas Jember, Jl. Kalimantan \\ Tegalboto No. 37, Krajan Timur, Sumbersari, Kec. Sumbersari, Jember, Indonesia \\ *e-mail: afridatul837@gmail.com
}

\begin{abstract}
Development Of High School Biology Non-Textbook Grade X Based On Ethnobotany Knowledge In Situbondo District. This study aims to produce nontextbooks based on ethnobotany in Situbondo district as a source of quality student learning with a valid, practical, and effective nature. The research used the Borg and Gall development model which consisted of 5 stages according to research needs. The research subjects were students from two class X MIPA at SMAN 1 Panarukan. Nontext books are validated by material expert validators, development experts, media experts, and linguists. The results of quantitative data analysis that have been validated by the validator with an average book value percentage of $85.75 \%$ are included in the eligibility criteria as very valid. The cloze test procedure results obtained an average percentage of $80.3 \%$ which is in the easy category. The average result of the $N$-Gain value is 0.58 which is included in the moderate effectiveness category. Non-text books that have been developed have good quality effectiveness, practicality, and readability to be used in classroom learning activities, especially on Kingdom Plantae material.
\end{abstract}

Keywords: etnobotany, learning resources, non-text book, validation

\begin{abstract}
Abstrak: Pengembangan Buku Nonteks Biologi SMA Kelas X Berbasis Pengetahuan Etnobotani Di Kabupaten Situbondo. Penelitian ini bertujuan untuk menghasilkan buku nonteks berbasis etnobotani kabupaten Situbondo sebagai sumber belajar siswa yang berkualitas dan bersiffat valid, praktis, dan efektif. Penelitian menggunakan model pengembangan Borg and Gall yang terdiri dari 5 tahapan sesuai kebutuhan penelitian. Subjek penelitian adalah siswa dari dua kelas X MIPA di SMAN 1 Panarukan. Buku nonteks divalidasi oleh validator ahli materi, ahli pengembangan, ahli media, dan ahli Bahasa. Hasil analisis data kuantitatif yang telah divalidasi oleh validator dengan rata-rata persentase nilai buku $85,75 \%$ termasuk ke dalam kriteria kelayakan sangat valid. Hasil uji rumpang atau Cloze Test Procedure diperoleh rata-rata persentase sebesar $80,3 \%$ yang termasuk kategori mudah. Hasil rata-rata nilai N-Gain adalah 0,58 yang termasuk kategori efektivitas yang sedang. Buku nonteks yang telah dikembangkan memiliki kualitas efektivitas, kepraktisan, dan keterbacaan yang baik untuk digunakan dalam kegiatan pembelajaran di kelas khususnya pada materi Kingdom Plantae.
\end{abstract}

Kata kunci: Sumber belajar, buku nonteks, etnobotani, validasi 


\section{PENDAHULUAN}

Rendahnya kualitas pembelajaran terjadi karena rendahnya kualitas pemanfaatan sumber belajar oleh guru dan siswa. Berdasarkan hal tersebut maka penggunaan dan pengembangan bahan ajar sangat penting karena mampu meningkatkan aktivitas, kreativitas dan hasil belajar siswa (Suwarni, 2015). Pengembangan bahan ajar khususnya pada jenjang SMA mengacu pada keunggulan daerah lingkungan sekitar sebagai konteks pembelajaran (Arifin et al., 2018), salah satunya dalam pokok bahasan pemanfaatan tumbuhan yang memuat etnobotani khususnya di kabupaten Situbondo.

Etnobotani adalah ilmu botani mengenai pemanfaatan tumbuh-tumbuhan oleh manusia yang berkaitan langsung dengan lingkungan sekitar khususnya adat suku di kabupaten Situbondo (Albuquerque et al., 2017). Siswa yang berminat untuk mempelajari etnobotani masyarakat Situbondo cukup banyak, tetapi mengalami kesulitan untuk memperoleh buku pengayaan yang bermutu dan bermuatan kearifan lokal masyarakat Situbondo.

Pemilihan kabupaten Situbondo berdasarkan hasil wawancara terhadap ahli Etnobotani Desa Kendit yang dilaksanakan pada tanggal 11 November 2020 menyatakan bahwa, Desa Bugeman memiliki wisata tradisi Ojhung dan masyarakat Situbondo masih menerapkan pemanfaatan tumbuhan secara empiris hingga sekarang. Hal tersebut dibuktikan dengan adanya beberapa hasil penelitian terkait tumbuhan yang dimanfaatkan sebagai tanaman obat atau upacara adat (Afrianto et al., 2020), salah satunya oleh Syaputra (2019) di kabupaten Situbondo. Terdapat kendala yang dihadapi oleh ahli etnobotani berdasarkan hasil angket kebutuhan yaitu, kurangnya pengaplikasian pengetahuan dalam bentuk tertulis (belum dijadikan buku) sehingga siswa cenderung lupa dan tidak tahu informasi tradisi tersebut.

Berdasarkan hasil angket kebutuhan siswa dan guru kelas X MIPA SMAN 1 Panarukan yang dilaksanakan 15 Desember 2020 memberikan hasil bahwa dalam memahami materi Kingdom Plantae mengalami beberapa kendala. Menurut guru biologi kendala yang dihadapi yaitu, masih belum ada bahan ajar yang memuat pengetahuan tentang etnobotani kabupaten Situbondo. Menurut siswa kendala yang dihadapi yaitu, bahan ajar yang dipakai mencantumkan terlalu banyak nama latin tumbuhan yang tidak terdapat di lingkungan sekitar, buku yang digunakan kurang menarik, dan sebagian besar siswa belum mengetahui pemanfaatan tumbuhan dalam suatu tradisi atau budaya dikarenakan informasi yang disalurkan hanya secara lisan bukan tertulis. Bahan ajar yang diharapkan menarik dengan bahasa yang ringkas dan padat, banyak gambar/ilustrasi, berwarna, memiliki sumber yang jelas, dan saran guru biologi bahan ajar tersebut memuat nama spesies yang disandingkan dengan bahasa lokal beserta bukti fisik tumbuhan secara detail.

Berdasarkan hasil angket tersebut, pengembangan bahan ajar yang sesuai berupa buku nonteks. Buku nonteks adalah buku pendamping atau semua buku pengayaa pelajaran yang mampu mendukung proses pembelajaran di setiap jenjang pendidikan (Pusat Perbukuan, 2018). Tujuan penelitian ini adalah pengembangan buku nonteks biologi SMA kelas $\mathrm{X}$ berbasis pengetahuan etnobotani di kabupaten Situbondo untuk meningkatkan hasil belajar siswa khususnya pada materi Kingdom Plantae. 
Jenis penelitian ini adalah penelitian pengembangan (Research and Development). Penelitian terkait proses pengembangan dan analisis data hasil penelitian dilaksanakan di Program Studi Pendidikan Biologi, tempat uji coba di SMAN 1 Panarukan, Kabupaten Situbondo pada semester genap tahun pelajaran 2021/2022, yaitu pada bulan November sampai April 2021. Model pengembangan buku nonteks menggunakan model pengembangan Borg and Gall dengan 10 tahap yang disederhanakan menjadi 5 tahap sesuai kebutuhan penelitian yaitu, penelitian dan pengumpulan informasi (research and Information collecting), perencanaan (planning), pengembangan produk awal (develop preliminary from of product), uji coba lapangan (preliminary field testing), dan revisi produk (main product revision) (Rusnita et al., 2019).

Validasi dilakukan oleh ahli materi, ahli pengembangan, ahli media, ahli Bahasa, dan pengguna. Proses pengembangan buku nonteks dilakukan uji coba untuk mengetahui keterbacaan, kepraktisan, dan efektivitas dari buku nonteks melalui uji coba kelompok kecil yang terdiri dari 9 siswa dengan tingkat pengetahuan yang berbeda di kelas X MIPA 1 dan uji coba kelompok besar yang terdiri dari 29 siswa di kelas X MIPA 2 di SMAN 1 Panarukan. Analisis data secara kualitatif dan kuantitatif. Data hasil wawancara, angket kebutuhan, dan observasi dianalisis secara kualitatif, sedangkan data hasil uji keterbacaan, hasil Pre-test dan Pos-test, hasil angket keterlaksanaan pembelajaran serta respon siswa dianalisis secara kuantitatif.

\section{HASIL DAN PEMBAHASAN}

Hasil penilaian validasi oleh validator ahli materi, ahli pengembangan, ahli media, ahli Bahasa, dan pengguna dapat dilihat pada Tabel 1 .

Tabel 1. Analisis hasil penilaian validator buku nonteks

\begin{tabular}{|c|c|c|c|}
\hline Validator & Aspek yang dinilai & $\begin{array}{l}\text { Tingkat } \\
\text { validasi } \\
(\%)\end{array}$ & $\begin{array}{c}\text { Kriteria } \\
\text { Kelayakan }\end{array}$ \\
\hline \multirow[t]{3}{*}{ Materi } & Kesesuaian Materi dengan SK dan KD & \multirow{3}{*}{85} & \multirow{3}{*}{ Sangat Valid } \\
\hline & Keakuratan Materi & & \\
\hline & Kelayakan Penyajian & & \\
\hline \multirow[t]{6}{*}{ Pengembangan } & $\begin{array}{l}\text { Tahapan pengembangan Pengumpulan } \\
\text { informasi }\end{array}$ & \multirow{6}{*}{80} & \multirow{6}{*}{ Valid } \\
\hline & Tahapan Pengembangan Perencanaan dan & & \\
\hline & Pengembangan Produk Awal & & \\
\hline & $\begin{array}{l}\text { Tahapan Pengembangan Uji Coba, Revisi, } \\
\text { dan Penyempurnaan produk hasil uji } \\
\text { lapangan }\end{array}$ & & \\
\hline & $\begin{array}{l}\text { Tahapan Pengembangan Penyempurnaan } \\
\text { produk akhir }\end{array}$ & & \\
\hline & $\begin{array}{l}\text { Tahapan Pengembangan Penyebaran dan } \\
\text { distribusi }\end{array}$ & & \\
\hline \multirow[t]{4}{*}{ Media } & Kelayakan Kegrafikan & \multirow{4}{*}{82} & \multirow{4}{*}{ Sangat Valid } \\
\hline & Kelayakan Bahasa & & \\
\hline & Kemenarikan Isi & & \\
\hline & Kelayakan Penyajian & & \\
\hline \multirow[t]{3}{*}{ Bahasa } & $\begin{array}{l}\text { Komponen Kesesuaian Dengan Tingkat } \\
\text { Perkembangan Peserta Didik }\end{array}$ & \multirow{3}{*}{88.5} & \multirow{3}{*}{ Sangat Valid } \\
\hline & Komponen Kekomunikatifan & & \\
\hline & $\begin{array}{l}\text { Komponen Keruntutan Dan Keterpaduan } \\
\text { Alur Pikir }\end{array}$ & & \\
\hline
\end{tabular}




\begin{tabular}{|c|c|c|c|}
\hline Validator & Aspek yang dinilai & $\begin{array}{c}\text { Tingkat } \\
\text { validasi } \\
(\%)\end{array}$ & $\begin{array}{c}\text { Kriteria } \\
\text { Kelayakan }\end{array}$ \\
\hline \multirow[t]{3}{*}{ Pengguna } & Kesesuaian Materi dengan SK dan KD & \multirow{3}{*}{96} & \multirow{3}{*}{ Sangat Valid } \\
\hline & Keakuratan Materi & & \\
\hline & Kelayakan Penyajian & & \\
\hline \multicolumn{2}{|c|}{ Rata-rata hasil validasi seluruh ahli } & 85,75 & Sangat Valid \\
\hline
\end{tabular}

Hasil pada Tabel 1. menunjukkan hasil analisis data kuantitatif dengan rata-rata persentase nilai buku nonteks $85,75 \%$ termasuk ke dalam kriteria kelayakan sangat valid yang menyatakan bahwa produk siap diuji coba lapangan dalam kegiatan pembelajaran.

Tahap uji coba lapangan terdiri dari uji coba kelompok kecil dan uji coba kelompok besar. Data hasil uji coba kelompok kecil adalah hasil uji keterbacaan menggunakan lembar Cloze Test Procedure dapat dilihat pada Tabel 2.

Tabel 2. Hasil uji keterbacaan buku nonteks pada uji coba kelompok kecil

\begin{tabular}{llcccc}
\hline No. & \multicolumn{1}{c}{ Nama } & $\begin{array}{c}\text { Jawaban } \\
\text { benar }\end{array}$ & $\begin{array}{c}\text { Jumlah } \\
\text { soal }\end{array}$ & $\begin{array}{c}\text { Tingkat } \\
\text { keterbacaan } \\
(\%)\end{array}$ & $\begin{array}{c}\text { Kriteria } \\
\text { Kelayakan }\end{array}$ \\
\hline 1 & Adennia & 25 & 30 & 83 & Mudah \\
\hline 2 & Desty Aulia Rifayanti & 27 & 30 & 90 & Mudah \\
\hline 3 & Fitria Dwi Lestari & 20 & 30 & 66,6 & Mudah \\
\hline 4 & $\begin{array}{l}\text { Muhammad Fajar } \\
\text { Priyadi }\end{array}$ & 26 & 30 & 86,6 & Mudah \\
\hline 5 & Nabila Syeira & 24 & 30 & 80 & Mudah \\
\hline 6 & Nanda Kartika Nur & 28 & 30 & 93,3 & Mudah \\
& Istiqomah & 23 & 30 & 76,6 & Mudah \\
\hline 7 & Revivia kahisyah & 24 & 30 & 80 & Mudah \\
\hline 8 & Syarifa Wulan & 20 & 30 & 66,6 & Mudah \\
\hline 9 & Triana Aulia & $\mathbf{2 1 7}$ & & $\mathbf{7 2 2 , 7}$ & \\
\hline & $\quad$ Jumlah & $\mathbf{2 4 , 1}$ & & $\mathbf{8 0 , 3}$ & Mudah \\
\hline
\end{tabular}

Hasil uji rumpang atau Cloze Test Procedure pada Tabel 2. diperoleh rata-rata persentase sebesar $80,3 \%$ yang termasuk kategori mudah, sehingga buku nonteks memiliki kualitas kepraktisan dan keterbacaan yang baik dan dapat diterapkan, selain itu diperoleh data hasil belajar siswa yang telah menggunakan buku nonteks. Data hasil belajar siswa diperoleh melalui uji coba kelompok besar menggunakan hasil Pre-test dan Pos-test mengenai efektivitas buku nonteks yang dapat dilihat pada Tabel 3.

Tabel 3. Hasil belajar siswa pada uji kelompok besar

\begin{tabular}{|c|c|c|c|c|c|}
\hline $\begin{array}{c}\text { Nama } \\
\text { Sekolah }\end{array}$ & $\begin{array}{c}\text { Jumlah } \\
\text { Siswa }\end{array}$ & $\begin{array}{c}\text { Rerata } \\
\text { Pretest }\end{array}$ & $\begin{array}{c}\text { Rerata } \\
\text { postest }\end{array}$ & N-Gain & $\begin{array}{c}\text { Kategori } \\
\text { N-Gain }\end{array}$ \\
\hline $\begin{array}{c}\text { SMAN 1 } \\
\text { Panarukan }\end{array}$ & 29 & 36 & 73,62 & 0,58 & Sedang \\
\hline
\end{tabular}


Hasil pada Tabel 3. menunjukkan rata-rata nilai N-Gain yang dilakukan di kelas X MIPA 2 di SMAN 1 Panarukan pada 29 siswa adalah 0,58 yang termasuk kategori efektivitas yang sedang. Buku nonteks yang telah dikembangkan memiliki kualitas efektivitas yang baik untuk digunakan dalam kegiatan pembelajaran di kelas khususnya pada materi Kingdom Plantae dan mampu meningkatkan hasil belajar siswa.

Pengembangan buku nonteks yang dilakukan oleh peneliti menggunakan model pengembangan Borg and Gall dengan 5 tahapan yang dilakukan dalam Penelitian, yaitu: (1) Penelitian atau pengumpulan informasi (research and Information collecting); (2) Perencanaan (planning); (3) Pengembangan produk awal (develop preliminary from of product); (4) Uji coba lapangan (preliminary field testing); dan (5) Revisi produk utama (main product revision) (Rusnita et al., 2019). Hasil yang diperoleh dari setiap tahapan pengembangan dapat diuraikan sebagai berikut.

Tahapan awal penelitian dan pengumpulan informasi terdiri dari 3 aspek diantaranya, mengkaji kurikulum dan materi, analisis SK, KD, Indikator, serta Studi literatur. Pengumpulan informasi dapat diperoleh melalui observasi kelas, wawancara, studi literatur dan analisis angket kebutuhan yang telah dilaksanakan pada desember 2020 terhadap guru biologi kelas X MIPA di SMAN 1 Panarukan. Berdasarkan hasil wawancara diperoleh data bahwa kurikulum yang digunakan berupa kurikulum 2013 Revisi, akan tetapi saat ini dikarenakan kondisi Pandemi COVID-19 menggunakan kurikulum darurat yaitu terdapat beberapa materi tidak disampaikan atau pemangkasan materi sehingga dalam penyampaian materi dirasa kurang dalam menyampaikan contoh tumbuhan secara morfologi dan bagiannya, salah satu sub materi yang dirasa sulit yaitu, materi Kingdom Plantae.

Analisis kebutuhan dilakukan dengan penyebaran angket kebutuhan kepada siswa, guru biologi kelas X MIPA di SMAN 1 Panarukan secara daring melalui Google Formulir dan ahli etnobotani di kabupaten Situbondo. Data yang diperoleh menurut analisis angket kebutuhan siswa yaitu, buku yang digunakan oleh siswa kurang menarik, dikarenakan terlalu banyak tulisan, terlalu banyak hafalan, dan buku yang digunakan oleh siswa belum memuat pemanfaatan tumbuhan di lingkungan sekitar sebagai budaya atau obat secara tradisional oleh masyarakat Situbondo.

Permasalahan lain yang berasal dari hasil angket kebutuhan guru yaitu, guru menggunakan buku teks pelajaran yang berjudul Buku Siswa Biologi Kelas X. Penggunaan buku tersebut efektif hanya saja buku terkesan sudah jadul, kuno, konvensional, dan tidak mengikuti perkembangan zaman. Hasil tersebut didukung dengan hasil angket analisis ahli etnobotani kabupaten Situbondo yang menyatakan bahwa kurangnya pengaplikasian pengetahuan dalam bentuk tertulis (belum dijadikan buku) sehingga siswa cenderung lupa dan tidak tahu informasi tradisi tersebut, secara keseluruhan hasil tersebut sebagai bahan untuk tahapan selanjutnya dalam mengembangkan sumber belajar sesuai kebutuhan.

Tahapan perencanaan yang terdiri dari tahapan perumusan tujuan, perencanaan kegiatan dan penyusunan instrumen (Rusnita et al., 2019). Peneliti merumuskan tujuan pembelajaran untuk menggambarkan hasil belajar sesuai KD (Kompetensi Dasar) yang telah ditentukan sehingga siswa mampu mencapai Kompetensi Dasar (Kurniasari et al., 2020). Model Discovery Learning dipilih untuk mencapai tujuan pembelajaran secara daring, karena dalam prosesnya menggunakan kegiatan dan pengalaman langsung sehingga dapat menarik perhatian siswa serta kegiatannya pun lebih realistik (Rosarina, 2016). Perencanaan kegiatan tersebut disusun kedalam RPP daring yang menggunakan 
aplikasi Google Meet didampingi oleh Ibu Shanty Noor sebagai guru biologi kelas X MIPA SMAN 1 Panarukan.

Penyusunan instrumen perangkat pembelajaran yang terdiri dari Silabus, RPP daring, lembar Cloze Test Procedure, lembar penilaian sikap dan keterampilan, lembar validasi soal, soal Pre-test dan Pos-test, Rubrik penilaian, kisi-kisi soal Pre-test dan Pos-test, serta angket respon siswa. Instrument perangkat pembelajaran digunakan untuk mempermudah mendapatkan bahan penelitian dalam setiap tahapan yang akan dilaksanakan serta dapat menghasilkan buku nonteks yang efektif dan praktis bagi siswa (Hendrayati et al., 2014).

Tahapan pada pengembangan produk awal terdiri dari penyusunan bahan ajar (draf produk awal) produk yang akan dikembangkan berupa buku nonteks yang dilengkapi dengan dokumentasi pribadi tentang tumbuhan secara detail dengan skala ukuran tumbuhan aslinya, ilustrasi (gambar) materi dari berbagai referensi buku, keterangan ilustrasi sesuai dengan gambar yang disajikan, dilengkapi dengan berbagai fitur yang menarik dan terupdate, dan petunjuk penggunaan buku (Sulistri et al., 2020). Buku nonteks juga dilengkapi dengan Link Youtube dan QR Code video secara proporsional agar siswa tidak bosan dalam membaca dan mempelajari buku nonteks tersebut. Materi Kingdom Plantae (Bryophyta, Pterydophyta, Spermatophyta, dan Etnobotani pengetahuan masyarakat Situbondo) sesuai dengan kurikulum 2013, standar isi, dan Kompetensi Dasar (Borolla et al., 2019), berikut desain beberapa bagian buku nonteks biologi dapat dilihat pada Gambar 1. Buku nonteks yang telah dikembangkan kemudian divalidasi untuk mengetahui kelayakan buku tersebut.
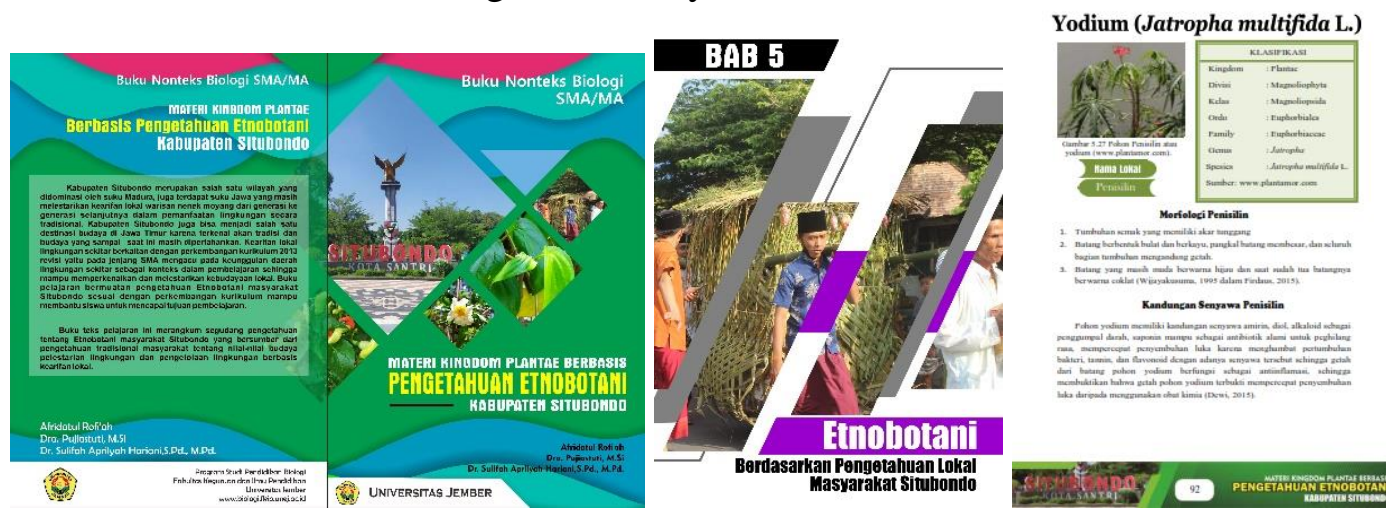

Gambar 1. Desain beberapa bagian buku nonteks biologi

Validasi bertujuan untuk memberikan nilai dan menentukan kelayakan dari buku nonteks sebelum di uji coba lapangan (Ilmiawan, 2018). Hasil analisis data kuantitatif oleh validator ahli materi berdasarkan kriteria aspek kesesuaian materi dengan SK dan $\mathrm{KD}$, keakuratan materi, dan kelayakan penyaji diperoleh rata-rata nilai sebesar $85 \%$ dengan kriteria kelayakan sangat valid, hasil validasi oleh ahli pengembangan berdasarkan kriteria aspek sesuai dengan tahapan model pengembangan yang digunakan diperoleh rata-rata nilai sebesar $80 \%$ dengan kriteria kelayakan valid.

Hasil validasi oleh ahli media berdasarkan kriteria aspek kelayakan kegrafikan, Bahasa, kemenarikan isi, dan kelayakan penyajian diperoleh rata-rata nilai sebesar $82 \%$ dengan kriteria kelayakan sangat valid, hasil validasi oleh ahli Bahasa berdasarkan kriteria komponen kesesuaian dengan tingkat siswa, perkembangan peserta didik, komponen kekomunikatifan, dan komponen keruntutan diperoleh rata-rata nilai sebesar 88,5\% dengan kriteria kelayakan sangat valid. 
Hasil validasi oleh ahli pengguna diperoleh rata-rata nilai sebesar $96 \%$ dengan kriteria kelayakan sangat valid, secara keseluruhan hasil validasi oleh para ahli memiliki rata-rata nilai sebesar $86,3 \%$ yang menyatakan produk layak untuk digunakan oleh siswa dan guru pada saat kegiatan pembelajaran. Hasil validasi tidak hanya berupa skor dan analisi persentase kelayakan, tetapi juga berdasarkan kritik dan saran para validator untuk perbaikan selanjutnya.

Beberapa saran dan komentar dari Tim ahli validasi yaitu, terdapat tulisan yang kurang rapi dan kontras, keterangan tabel diletakkan dalam paragraf, setiap halaman menggunakan border/header dengan warna hijau menyala diusahakan pakai warnawarna pastel atau kalem, lebih baik ditambahkan daftar kosakata lokal Bahasa Madura dan Bahasa Jawa, serta tujuan pembelajaran disesuaikan dengan tujuan pembelajaran di RPP daring.

Penilaian buku nonteks setelah di revisi berdasarkan saran dan komentar dari tim validasi, selanjutnya di uji coba lapangan yang terdiri dari uji coba kelompok kecil dan uji kelompok besar. Uji kelompok kecil adalah uji coba keterbacaan terhadap 9 siswa kelas X MIPA 1 di SMAN 1 Panarukan dengan tingkat pengetahuan yang berbeda selama dua kali pertemuan. Hasil uji rumpang atau Cloze Test Procedure diperoleh ratarata persentase sebesar $80,3 \%$ yang termasuk kategori mudah, sehingga buku nonteks memiliki kualitas kepraktisan dan keterbacaan yang baik dan dapat diterapkan. Buku nonteks yang digunakan pada uji coba kelompok kecil mendapatkan saran dan komentar dari angket respon siswa sehingga diperlukannya revisi sebelum digunakan untuk uji coba kelompok besar.

Merevisi hasil uji coba produk awal/ uji coba kecil (main product revision), tahapan ini untuk merevisi buku nonteks yang telah digunakan pada uji coba kecil berdasarkan kritik dan saran yang terdapat di angket respon siswa dari uji coba kecil yang akan disempurnakan. Beberapa saran dan komentar dari angket respon siswa yaitu, pada bagian cover depan buku gambar yang digunakan kurang representatif karena kurang menonjolkan aspek pemanfaatan tumbuhan dan cenderung menonjolkan aspek budaya kabupaten Situbondo. Buku nonteks yang telah direvisi dapat digunakan untuk uji coba kelompok luas dengan jumlah responden yang lebih banyak.

Uji coba kelompok besar menggunakan Pre-test dan Pos-test untuk mengetahui efektivitas dari penggunaan buku nonteks yang telah dikembangkan (Suwarni, 2015). Uji coba kelompok besar dilaksanakan kepada 29 siswa kelas X MIPA 2 di SMAN 1 Panarukan. Data yang diperoleh pada kegiatan uji coba kelompok besar berupa hasil Pre-test dan Pos-test mengenai efektivitas buku nonteks dengan rata-rata nilai N-Gain adalah 0,58 yang termasuk kategori efektivitas yang sedang. Buku nonteks yang telah dikembangkan memiliki kualitas efektivitas yang baik untuk digunakan dalam kegiatan pembelajaran di kelas khususnya pada materi Kingdom Plantae dan mampu meningkatkan hasil belajar siswa.

Hasil tersebut menunjukkan bahwa adanya peningkatan hasil belajar oleh siswa setelah menggunakan buku nonteks yang telah dikembangkan menunjukkan bahwa buku nonteks tersebut memiliki kualitas efektivitas, kepraktisan dan keterbacaan yang baik untuk digunakan dalam kegiatan pembelajaran. Merujuk pada hasil penelitian (Rosnawati \& Kaharudin, 2020), bahwa keefektivan disebabkan salah satunya oleh sumber belajar yang digunakan oleh siswa dalam pembelajaran.

Berdasarkan hasil validasi, uji coba kelompok kecil, dan uji coba kelompok besar penggunaan buku nonteks yang dilaksanakan di SMAN 1 Panarukan, maka produk buku nonteks yang berjudul "Materi Kingdom Plantae Berbasis Pengetahuan Etnobotani 
Kabupaten Situbondo" dinyatakan layak digunakan sebagai buku pengayaan pengetahuan.

\section{SIMPULAN}

Hasil uji validasi pengembangan buku nonteks tergolong sangat valid dengan nilai rata-rata persentase $86,3 \%$ yang menyatakan produk layak digunakan oleh siswa dan guru pada saat kegiatan pembelajaran untuk meningkatkan hasil belajar siswa. Hasil efektivitas pengembangan buku nonteks tergolong efektif berdasarkan hasil nilai ratarata Normalized Gain yang termasuk kategori sedang yaitu, 0,58 di kelas X MIPA SMAN 1 Panarukan sehingga tergolong efektif dalam meningkatkan hasil belajar siswa, sehingga produk buku nonteks yang berjudul "Materi Kingdom Plantae Berbasis Pengetahuan Etnobotani Kabupaten Situbondo" dinyatakan layak, efektif, dan praktis untuk digunakan sebagai buku pengayaan pengetahuan

\section{DAFTAR RUJUKAN}

Afrianto, W. F., Tamnge, F., \& Hasanah, L. N. U. R. (2020). Review : A Relation Between Ethnobotany And Bioprospecting Of Edible Flower Butterfly Pea ( Clitoria Ternatea ) In Indonesia. Asian Journal of Ethnobiology, 3(2), 51-61. Albuquerque, U. P., Ramos, M. A., Junior, W. S. F., \& Medeiros, P. M. (2017). Ethnobiology For Beginners. Switzerland: Springer International Edited by.

Arifin, M. Z., Ulfa, S., \& Praherdhiono, H. (2018). Pengembangan kurikulum muatan lokal karawitan sebagai upaya mengkonstruksi pengetahuan dan pelestarian budaya jawa di jenjang sma. Jurnal Kajian Teknologi Pendidikan, 1(2), 2-10. http://journal2.um.ac.id/index.php/jktp/article/view/3707.

Borolla, F. V., L. Yuliati, dan I. M. Suardana. (2019). Keefektifan dan Minat Baca Siswa pada Penggunaan Buku Pengayaan Non Fiksi di SD. Jurnal Pendidikan Teori Penelitian dan Pengembangan, 4(12), 1715-1722.

Hendrayati, T., Na'im, M., \& Umamah, N. (2014). Pengembangan Bahan Ajar Sejarah Berbasis Pendekatan Saintifik Pada Sub Pokok Bahasan Kerajaan Majapahit Kelas X Sma Negeri 1 Bangorejo. Artikel Ilmiah Mahasiswa, 1(1), 1-11.

Ilmiawan, A. (2018). Pengembangan Buku Ajar Sejarah Berbasis Situs Sejarah Bima (Studi Kasus pada Siswa Kelas X MAN 2 Kota Bima). Jurnal Ilmu Sosial Dan Pendidikan, 2(3), 102-106.

Kurniasari, A., Pribowo, F. S. P., \& Putra, D. A. (2020). Analisis Efektivitas Pelaksanaan Belajar Dari Rumah (Bdr) Selama Pandemi Covid-19. Jurnal Review Pendidikan Dasar: Jurnal Kajian Pendidikan Dan Hasil Penelitian, 6(3), 1-8.

Rusnita, D., Hambali, D. \& Winarni, E. W. (2019). Pengembangan Bahan Ajar Buku Cerita Berbasis Discovery Learning Pada Materi IPA Konsep Perpindahan Panas Di Kelas V Sekolah Dasar. Jurnal Pembelajaran dan Pengajaran Pendidikan Dasar, 2(2), 199-209.

Sulistri, E., Sunarsih, E. \& Utama, E. G. (2020). Pengembangan Buku Saku Digital Berbasis Etnosains di Sekolah Dasar Kota Singkawang. Jurnal Kependidikan, 6(3), 522-531.

Rosarina, G., Sudin, A., \& Sujana, A. (2016). Penerapan Model Discovery Learning Untuk Meningkatkan Hasil Belajar Siswa Pada Materi Perubahan Wujud Benda. Jurnal Pena Ilmiah, 1(1), 371-380. https://doi.org/10.17509/jpi.v1i1.3043 
Pusat Perbukuan. (2018). Panduan Pemilihan Buku Nonteks Pelajaran. Jakarta: Pusat Kurikulum dan Perbukuan Kemendikbud.

Rosnawati, V., \& Kaharudin, L. ode. (2020). Pengembangan Ensiklopedia Berbasis Potensi Lokal Yang Terdapat Di Wakatobi Pada Materi Pokok Animalia Invertebrata (Mollusca Dan Echinodermata). JIKAP PGSD: Jurnal Ilmiah Ilmu Kependidikan, 4(1), 84-94. https://doi.org/10.26858/jkp.v4i1.12055.

Suwarni, E. (2015). Pengembangan Buku Ajar Berbasis Lokal Materi Keanekaragaman Laba-Laba Di Kota Metro Sebagai Sumber Belajar Alternatif Biologi Untuk Siswa Sma Kelas X. BIOEDUKASI (Jurnal Pendidikan Biologi), 6(2), 86-92. https://doi.org/10.24127/bioedukasi.v6i2.336. 